\title{
DOES CORPORATE SUSTAINABILITY PRACTICES HAVE AN IMPACT ON FINANCIAL PERFORMANCE: A STUDY BASED ON BIST MANUFACTURING FIRMS
}

\author{
DOI: 10.17261/Pressacademia.2018.971 \\ PAP-IFC- V.8-2018(3)-p.9-13
}

\section{Nevzat Gungor ${ }^{1}$, Ceren Dincel ${ }^{2}$}

${ }^{1}$ Istanbul University, Avcilar Campus, School of Business Administration, Accounting Department, Istanbul, Turkey. nevzat.gungor@istanbul.edu.tr, ORCID: 0000-0001-9883-1985

${ }^{2}$ Istanbul University, Avcilar Campus, School of Business Administration, Accounting Department, Istanbul, Turkey. ceren.dincel@istanbul.edu.tr, ORCID: 0000-0002-3665-2452

\section{To cite this document}

Gungor, N., Dincel, C. (2018). Does corporate sustainability practices have an impact on financial performance: A study based on BIST manufacturing firms. PressAcademia Procedia (PAP), V.8, p.9-13.

Permemant link to this document: http://doi.org/10.17261/Pressacademia.2018.971

Copyright: Published by PressAcademia and limited licenced re-use rights only.

\begin{abstract}
Purpose- Corporate Sustainability notion has become very important in recent years with sustainable development, which is defined as fulfillment of current needs without risking fulfillment of future generations' needs. Especially in the last two decades, the relationship between financial performance and corporate sustainability has been questioned extensively in large masses particularly business and academic world. The purpose of this study is to analyze the corporate sustainability practices and its impact on financial performance.

Methodology - It focuses on relationship between corporate sustainability practices and financial performance. In order to reach this aim corporate sustainability checklist is established and companies are classified according to their sustainability levels. Publicly traded companies from BIST 100 (excluding finance sector) are used as a sample. Data is gathered from theirs annual reports for the years between 2012-2017.

Findings- MANOVA analysis is used to analyze the relationship between the sustainability levels and the financial performance indicators. The results implied that sustainability levels have statistically significant effect between the group means of 3 variables. These are Current Ratio, Gross Profit Margin and Corporate Governance Index. For Current Ratio variable, there is a significant difference between sustainable and least sustainable category for $10 \%$ significance level. For CG Index variable, there is a significant difference between most sustainable and sustainable category and most sustainable and least sustainable category for $5 \%$ significance level. For Gross Profit Margin variable, there is a significant difference between most sustainable and sustainable category for $5 \%$ significance level.

Conclusion- In many studies it is found that there is a positive relationship between corporate social sustainability and firm financial performance. Our study supports that companies incorporate sustainability issues into their business operations are better able to leverage their resources toward stronger financial performance and shareholder value creation. We were able find a significant relationship between Current Ratio, Gross Profit Margin and Corporate Governance Index. The paper contributes to the literature by offering a more holistic approach to corporate sustainable performance measurement and its relationship between financial performance.
\end{abstract}

Keywords: Sustainable development, corporate sustainability, financial performance, Borsa Istanbul. JEL Codes: Q01, M40, G30

\section{INTRODUCTION}

In today's economic world, traditional business model is no longer possible. Globalization, technological and demographical changes have lead to the change in the internal organization structures, processes and behavior. Environmental, social and governance issues are becoming extremely powerful for gaining competitive advantage on the global market. Whether the corporate sustainable performance affects the financial performance is still unclear in many companies.

In this study, in order to examine the relationship between the sustainability level and the financial performance indicators of Turkish companies, a sustainability checklist is established by using Dow Jones Corporate Sustainability Assessment Methodology. The rest of the paper is organized as follows: Section 2 provides a detailed survey of past studies. Section 3 explains the data (variables employed) and methodology while the results are presented in Section 4. Finally, Section 5 gives the conclusion.

\section{LITARATURE REVIEW}

Collison, et.al (2008) examines the financial performances of the FTSE4Good indices. They found that companies that satisfy FTSE4Good's corporate social responsibility criteria do no worse than their counterparts who do not follow a socially responsible strategy when purchasing equities. Aras, et.al (2010), investigate the relationship between corporate social responsibility and firm financial performance. 
Although they found a relationship between firm size and corporate social responsibility, they were not able to find any significant relationship between corporate social responsibility and financial performance/profitability

Vitezić (2011), aims to establish if there is a correlation between efficiency and socially responsible business performance in Croatian enterprises. The conclusion is derived that there is a causal relationship between efficiency and social responsibility, i.e. higher efficiency level enables higher allocation of resources with the purpose of socially more responsible corporate performance and vice versa; socially responsible corporate performance have an impact on reputation and on improved efficiency, measured by financial indicators. Skare \& Golja (2012), analyzes the importance of socially responsible business practices for the Corporations. They find that CSR firms in the average enjoy better financial performance that non-CSR firms.Tang, et al. (2012), propose that firm profits are shaped by how firms engage in corporate social responsibility. They find that firms benefit more when they adopt a CSR engagement strategy that is consistent, involves related dimensions of CSR, and begins with aspects of CSR that are more internal to the firm. The pace of the CSR engagement strategy, however, does not moderate the CSR-CFP relationship. Rodriguez-Fernandez (2015), investigates the bidirectional relationship between Corporate Social Responsibility and Financial Performance in Spanish listed companies. The study demonstrates positive relationships, that the social is profitable and that the profitable. They are proof that all social policies increment financial resources, and vice versa, that increased financial performances lead to greater social benefits. Cheng et. al (2016), examine the relationship between the issuance of CSR reports and performance, in terms of accounting income, market return, and growth by firms listed in China in $2008-2009$. They find that the historical performance of firms has significant and positive effects on the issuance of standalone CSR reports. There is also a positive correlation between current CSR disclosures and subsequent performance.

DiSegni et.al (2015), aims to statistically assess the relationship between corporate characteristics, environmental contribution and financial performance. Firms that are proactive in supporting social responsibility and environmental sustainability (SRES corporations) are characterized by significantly higher profit measures than the industry and the sector, though not higher than the entire market. They have lower short-term liquidity measures than those of the industry and related sector, and surprisingly, their long-term leverage is significantly higher. Strong SRES corporations are characterized by significantly higher managerial efficiency ratios than the respective industry and sector. Saeidi et.al (2015), considers sustainable competitive advantage, reputation, and customer satisfaction as three probable mediators in the relationship between CSR and firm performance. Taken together, these findings suggest a role for CSR in indirectly promoting firm performance through enhancing reputation and competitive advantage while improving the level of customer satisfaction. Chen et.al (2015), investigates the relationship between the disclosure of corporate social performance and the financial performance. Results indicate that the categories of Human Rights, Society as well as Product responsibility display a significant and positive correlation with the return on equity. Same conclusional so holds for many CSR indicators. Nevertheless, when examining the CSR practices across different manufacturing sectors, we have not observed significant differences. Testa \& D'Amato (2017), aims to explore as good environmental results can lead to good financial results. Although the findings do not support bidirectional hypothesis, they establish direction/causality from CFP to CER. As a result, environmental responsibility is a consequence of prior financial performance, which supports the slack resources hypothesis.

Oikonomou, et. al (2012), focuses on the wealth-protective effects of socially responsible firm behavior by examining the association between corporate social performance (CSP) and financial risk. The main findings are that corporate social responsibility is negatively but weakly related to systematic firm risk and that corporate social irresponsibility is positively and strongly related to financial risk. Charlo et.al (2015), used an empirical analytical method to determine possible differences between the financial variables of firms considered to be socially responsible and those not considered to be such. The results obtained show that socially responsible corporations obtain higher profits for the same level of systematic risk and show greater sensitivity to market changes, leverage levels and company size.

Wagner (2010) analyses the link between sustainability management and economic performance. The results indicate that there is no moderating role on the link between corporate sustainability and economic performance is identified. Goyal (2013), investigates the relation of sustainability performance and firm performance. The review reveals that most of the research in the field of sustainability performance and firm performance association, analyzed this relationship in developed countries. The result differs in various cultural and economic contexts and there is no universally accepted direction of this relationship. Cunha and Samanez (2013), study the Corporate Sustainability Index (ISE) of the Brazilian Mercantile, Futures and Stock Exchange (BM\&FBOVESPA), with the main objective of analyzing the performance of sustainable investments in the Brazilian stock market, during the period from December 2005 to December 2010 . The results show that although sustainable investments have presented some interesting characteristics, such as increasing liquidity and low diversifiable risk, they did not achieve satisfactory financial performance in the analysis period. This indicates that the constraints imposed by this type of investment in capital allocation in Brazil may be harming their return and risk attractiveness.

Ameer and Othman (2012), test the relationship between sustainable practices and financial performance. Their findings show that the higher financial performance of sustainable companies has increased and been sustained over the sample. And also, there is bidirectional relationship between corporate social responsibilities practices and corporate financial performance. Eccles et al. (2014), investigate the effect of corporate sustainability on organizational processes and performance. They provide evidence that High Sustainability companies significantly outperform their counterparts over the long-term, both in terms of stock market as well as accounting performance. GomezBezares et al. (2017) exemine the effect of integrating sustainability into corporate strategy on various aspects of shareholder value creation and financial performance in the British capital market. The results support the thesis that firms that incorporate sustainability issues into their business operations are better able to leverage their resources toward stronger financial performance and shareholder value creation than other companies. 


\section{DATA AND METHODOLOGY}

This study tests the relationship between corporate sustainability practices and financial performance indicators of firms on a sample of listed BIST 100 companies over the 2012-2017 period. The sample only consists of the 46 largest companies which are listed in BIST 100 index.

This study focuses on sources of information that are most readily accessible by local and international investors - typically the latest available annual reports in English and Turkish web sites. In this framework, the sustainability levels of disclosures in annual reports are calculated by establishing a sustainability checklist.

Sustainability assessment consists of three main dimensions: Economic, Environmental and Social. In the sustainability checklist, 25 criteria (Economic -11, Environmental-7, and Social-7) is derived from Dow Jones Corporate Sustainability Assessment Methodology.

If the relevant information in the annual report is found, " 1 " is assigned to the company. Otherwise, the company gets "0" point. Firstly, total scores of each dimension are calculated within themselves. Thereafter, total sustainability scores are found. After calculating these sustainability level scores of 46 companies, these companies are divided into 3 categories as shown in Table 1 and MANOVA Analysis (Multivariate Analysis of Variance) is applied to investigate whether there is a significant difference between means of at least one financial ratio of at least two groups of sustainability categories.

Table 1: Category Diversification of Firms

\begin{tabular}{|c|c|c|c|}
\hline Categories & Category Name & Sustainability Level & $\begin{array}{c}\text { Total Number of } \\
\text { Companies }\end{array}$ \\
\hline 1 & Most Sustainable & $85 \%-100 \%$ & 6 \\
\hline 2 & Sustainable & $61 \%-84 \%$ & 21 \\
\hline 3 & Least Sustainable & $60 \%$ - below & 19 \\
\hline
\end{tabular}

Financial performance indicators are calculated to analyze relationship between financial performance and sustainability level of companies. The financial statements are gathered from FINNET database. 11 financial ratios (calculated as financial performance indicators) and 2 dummy variables (Corporate Governance Index, Sustainability Index ), totally 13 dependent variables are shown in Table 2:

Table 2: Financial Performance Indicators Used in the Paper

\begin{tabular}{ll}
\hline Financial Ratios & \\
\hline Current Ratio & Gross Profit Margin \\
Acid Test Ratio & Accounts Payable Turnover \\
Debt to Asset & Accounts Receivable Turnover \\
Debt to Equity & Inventory Turnover \\
Return on Asset & Sustainability Index \\
Return on Equity & Corporate Governance Index \\
Return on Sales & \\
\hline
\end{tabular}

MANOVA (Multivariate Analysis of Variance) is employed by SPSS 20 to evaluate group differences across the financial ratios simultaneously. MANOVA is a dependence technique that tests the differences for two or more metric dependent variables based on a set of nonmetric variables acting as independent variables. Manova analysis is applied in four steps: (1) multivariate tests: to test the basic assumption of Manova, (2) Levene's Test of Equality of Error Variances: to test for equality of error variances across dependent variables, (3) Test of Between-Subjects Effect: to investigate if the independent variable differ on all of the dependent measures, (4) Post hoc tests: to test the significance of differences in levels of an independent factor in comparison to a dependent variable.

\section{FINDINGS}

Manova analysis contains the most commonly used multivariate tests (Pillai's Trace, Wilk's Lambda, Hotelling's Trace and Roy's Largest Root). The basic hypothesis of Manova (the population means on the multiple dependent variables are equal across groups) is tested by the multivariate tests. According to results, the significance level of all tests are smaller than $5 \%$. Since the significance level of all tests are smaller than $5 \%$, each of the four measures indicate that there is a significant difference between the means of at least one dependent variable (financial ratio) of at least two groups of independent variable (sustainability levels of firms).

After significant results are attained by multivariate tests, for further investigation The Test of Between-Subjects effect is performed in relation to each of the dependent variables. The Test of Between- Subjects Effects analyzes whether there is a significant difference between the means of at least one financial ratio of at least two groups of the sustainability levels or not. The results show that the type of sustainability levels reveal the differences across the financial ratios namely Current ratio, Gross Profit Margin, and Corporate Governance index for $5 \%$ significance level.

After analyzing the results of The Test of Between- Subjects Effects, the next phase is to examine the results of the Levene Test. According to results, while the error variance of Gross Profit Margin is equal, the rest of them are not. Therefore Tukey Test is considered for Gross Profit Margin and Tamhane Test is considered for the others. After applying Tukey Test, for Gross Profit Margin, there is a significant difference between Most Sustainable and Sustainable categories for $5 \%$ significance level. After results are obtained from Tamhane Test, 
for Corporate Governance Index, there is a significant difference between each categories for 5 \% significance level. For Current Ratio, there is a significant difference between Sustainable and Least Sustainable categories for $10 \%$ significance level.

\section{CONCLUSION}

The aim of this study is to investigate the relationship between the sustainability level and the financial performance indicators of 46 companies, which are listed in BIST-100 index during the year 2017. After calculating this sustainability level scores of 46 companies, these companies are divided into 3 categories which are; most sustainable, sustainable, least sustainable.

MANOVA analysis is used to analyze the relationship between the sustainability levels and the financial performance indicators. The results implied that sustainability levels have statistically significant effect between the group means of 3 variables. These are Current Ratio, Gross Profit Margin and Corporate Governance Index.

For Current Ratio variable, there is a significant difference between sustainable and least sustainable category for $10 \%$ significance level. The mean of the first group is smaller than the second one. For CG Index variable, there is a significant difference between most sustainable and sustainable category and most sustainable and least sustainable category for $5 \%$ significance level. The mean of the first group is greater than the second and third one. For Gross Profit Margin variable, there is a significant difference between most sustainable and sustainable category for $5 \%$ significance level. The mean of the first group is greater than the second one.

For further studies, coefficients can be assigned to criteria in sustainability checklist in relation to importance of the subject. In this study, only the annual reports are examined. It can be also generalized for all sustainability/integrated reports. And to gain more information for Turkish market, all companies listed in BIST can be added to population of the study.

\section{REFERENCES}

Ameer, R., Othman, R. (2012). Sustainability practices and corporate financial performance: a study based on the top global corporations. Journal of Business Ethics, vol. 108, no. 1, p. 61-79.

Aras, G., Aybars, A., Kutlu, O. (2010). Managing corporate performance: Investigating the relationship between corporate social responsibility and financial performance in emerging markets. International Journal of Productivity and Performance Management, vol. 59, no. 3, p. 229-254.

Charlo, M.J., Moya, I., Munoz, A.M. (2015). Sustainable development and corporate financial performance: a study based on the FTSE4Good IBEX index. Business Strategy and the Environment, vol. 24, p. 277-288.

Chen, L., Feldmann, A., Tang, O. (2015). The relationship between disclosures of corporate social performance and financial performance: Evidences from GRI reports in manufacturing industry. International Journal of Production Economics, vol. 170, p. 445-456.

Cheng, S., Lin, K.,Z., Wong W. (2016). Corporate social responsibility reporting and firm performance: Evidence from China. Journal of Management and Governance, vol. 20, no. 3, p. 503-23.

Collison, D.J., Cobb, G., Power, D.M., Stevenson, L.A. (2008). The financial performance of the FTSE4Good indices. Corporate Social Responsibility and Environmental Management, vol. 15, no. 1, p. 14-28.

Cunha, F.A.F.S., Samanez C.P. (2013). Performance analysis of sustainable investments in the Brazilian stock market: a study about the corporate sustainability index (ISE). Journal of Business Ethics, vol. 117, no. 1 p. 19-36.

DiSegni, D.M., Huly, M., Akron, S. (2015). Corporate social responsibility, environmental leadership and financial performance. Social Responsibility Journal, vol. 11, no. 1, p. 131-148.

Eccles, R.G., Ioannou I., Serafeim, G. (2014) The impact of corporate sustainability on organizational processes and performance. Management Science, vol. 60, no. 11, p. 2381-2617.

Gomez-Bezares, F., Przychodzen, W., Przychodzen, J. (2017). Bridging the gap: How sustainable development can help companies create shareholder value and improve financial performance. Business Ethics: A European Review, vol. 26, no. 1, p. 1-17.

Goyal, P., Rahman, Z., Kazmi, A.A. (2013). Corporate sustainability performance and firm performance research: Literature review and future research agenda. Management Decision, vol. 51 no.2, p. 361-379.

Oikonomou, I., Brooks, C., Pavelin, S. (2012). The impact of corporate social performance on financial risk and utility: a longitudinal analysis financial management. Financial Management, vol. 41, no. 2, p. 483-515.

Rodriguez-Fernandez, M. (2016). Social responsibility and financial performance: the role of good corporate governance. Business Research Quarterly, vol. 19, no. 2, p. 137-151.

Saeidi, S.P., Sofian, S., Saeidi, P., Saeidi, S.P., Saaeidi, S.A (2015). How does corporate social responsibility contribute to firm financial performance? The mediating role of competitive advantage, reputation, and customer satisfaction. Journal of Business Research, vol. 68 , no. 2 , p. 341-350.

Skare, M., Golja, T. (2012). Corporate social responsibility and corporate financial performance - Is there a link? Economic ResearchEkonomska Istraživanja, vol. 25, p. 215-242. 
Tang, Z., Hull, C.E., Rothenberg, S. (2012). How corporate social responsibility engagement strategy moderates the CSR-financial performance relationship. Journal of Management Studies, vol. 49, no. 7, p. 1274-1303.

Testa, M., D’Amato, A. (2017). Corporate environmental responsibility and financial performance: Does bidirectional causality work? Empirical evidence from the manufacturing industry. Social Responsibility Journal, vol. 13, no. 2, p. 221-234.

Vitezic, N. (2011). Correlation between social responsibility and efficient performance in Croatian enterprises. Zb. rad. Ekon. fak. Rij., vol. 29 , no. 2 , p. $423-442$.

Wagner, M. (2010). The role of corporate sustainability performance for economic performance: a firm-level analysis of moderation effects. Ecological Economics, vol. 69, no. 7, p.1553-1560. 